\title{
LAWS, REGULATIONS, POLICIES, CONVENTIONS AND HAZARDS IN PAELEONTOLOGICAL COLLECTING, BUYING AND SELLING
}

WOLBERG, Donald L., * Natural History Development Company, 1013 John Paul Jones Drive, Aquia Harbour, Stafford, VA 22554, U.S.A.; REINARD, Patsy D., Attorney at Law, 206 Neel Avenue, Socorro, NM 87801, U.S.A.

In an age of complex interactions and contentiousness, the concerns of some interest groups are almost certain to collide with those of others. Two characteristics describe these conflicts--each group is certain of the correctness of its value system and each group seeks a political/legal remedy. Paleontology depends on access to fossils. Fossils are collected by a variety of people--paleontologists directly involved in paleontology, geologists indirectly concerned with fossils, commercial paleontologists, amateur paleontologists, a variety of nonpaleontologists for whom discoveries are serendipitous, and the interested public for whom fossils are of educational or entertainment interest. Fossils have educational, commercial, and artistic values, occur as part of mineral or other commercially valuable deposits on public lands managed for varying purposes and on Native American and private lands. Given the employment outlook in paleontology, the boundaries between interest groups is blurred and increasing numbers of individuals will move between groups at different stages in their careers.

Large portion of the western U.S. consist of federally managed public lands with responsibility held by a number of different agencies. Public lands are organized and regulated for grazing, mining, oil and gas, wilderness, wildlife refuges, etc. A subset of these categories includes plant, animal, and cultural resources, especially archeology. The introduction of paleontology to these subsets is a new event that is hard to resolve within the regulatory framework. The efforts to try to regulate paleontology result from a belief that access to and disposition of fossils is unregulated, substantive abuses exist, much scientific information is lost and legislative initiatives are needed. The counter position maintains that most fossils are lost to erosion not unregulated collecting, more benefits accrue from commercial activities than are ever lost, and regulations should codify these realities. Industry responses indicate that academic/research interests are attempting to define paleontology from an exclusive, noncommercial perspective of who can or cannot be a paleontologist. They maintain that commercial paleontologists have always been a part of paleontology and have made substantive contributions.

Much of the interest in legislation appears to be directed at the commercial paleontology industry. Concern has been expressed that this industry utilizes fossils for other than scientific/educational purposes, drives up prices paid for fossils, or illegally obtains fossils. Based on available information, the commercial industry is a negligibe ecomonic force and consists of about fifty companies that actively collect fossils in the U.S. with total annual cumulative sales of less than 30 million dollars. Data indicate that almost all "major" commercial specimens are sold to public institutions. As in academia, despite the general popularity of fossils, commercial paleontology is in decline

Access to lands and fossils already are impacted by a variety of laws, regulations, policies, contracts, and informal agreements. Most recent legislative initiatives have mirrored archeological legislation. However, a current draft bill is uniquely paleontologic in structure, intent, and content. 